which just over 10 per cent. were large mononuclear and 20 per cent. eosinophiles. Examination on March 30 th, nearly ten weeks later, showed a similar condition of the blood. His symptoms have been exactly the same-there is always blood in the urine, and at times he has to pass urine every half hour. Ova were found on both occasions and hatched out freely.

Consideration of these cases leaves no doubt that they were absolutely unaffected by the administration of salvarsan.

The first case was not followed up ; his liability to re-infection prevented his being a good test case. The chief point proved was that in his case salvarsan, given intramuscularly, exerted no effect on the life or discharge of the ova. Since it is this method which is stated by Dr. Joannides to have produced a complete absence of ova in all his cases in less than a week, it is useful for comparison.

The other two cases were injected intravenously. If any drug is to produce a rapid effect on parasites which live in the blood-vessels, clearly the most effective way is to introduce it directly into the circulation. Unluckily the death of the worms cannot be recognised by any immediate change in the symptoms, which depend, as has been explained above, on the presence of the eggs already laid in the tissues. The only possible indication of the death of the worms would be a marked fluctuation in the degree of eosinophilia, which would ultimately tend to disappear. This was accordingly investigated repeatedly with a negative result. The persistence of symptoms, and particularly the continued discharge of living eggs, leave no doubt that the effect on the eggs themselves was absolutely nil. Both cases were carefully watched over a sufficiently long period to establish this point.

We, therefore, conclude that salvarsan as a remedy for bilharziasis is absolutely valueless, and that it should not be used or recommended for this purpose.

\section{CAN AS GOOD RESULTS BE OBTAINED BY THE TREATMENT OF PULMONARY TUBERCULOSIS IN THE LOW- LANDS AS AT HIGH ALTITUDES ? 1}

By Professor CHR. SAUGMAN, MFDICAI DIRECTOR OF VEJLEFJORD SANATORILM, DENMARK.

SiNCE the year 1899, when Turban issued his famous book "Beitrïge zur Kenntniss der Lungentaberkulose," it has appeared to many physicians as an established dogma that a mountain climate, and more especially a high altitude climate, is one of the most important conditions for the treatment of pulmonary tuberculosis, and that the results which were obtained at the high altitudes in reality were far better than those which could be obtained in the lowlands. Turban's statistics were so much more satisfactory than those published hitherto that this opinion seemed to be well founded. Experienced authors, however (such as Meissen, Schröder, and others), have maintained the opposite standpoint, but up to now no proof based on statistics has been offered to show that it is possible to obtain just as good results at a low level as at a high altitude. On the other hand, there are still authors (for instance, Williams in his Harveian oration, $1911^{2}$ ) who strongly maintain that treatment at high altitudes is far superior to all other climatic or hygienic forms of treatment.

After having worked for some years in Denmark at Vejlefjord Sanatorium, which is close to the sea and only '25 metres above it, it was clear to me that our results were hardly inferior to Turban's, and now, after a period of 12 years' work, I consider myself entitled to offer the proof thereof based on statistics.

I am well aware that it is extremely difficult to compare the results of two methods of treatment, or the results from two sanatoriums, and that it is very easy to go astray into a wilderness of statistical lies. It would not be correct to make a simple comparison between the figures obtained from different localities, especially with regard to the results gained at the time of the patient's discharge, when a more or

1 A paper read before the International Congress on Tuberculosis at Rome, April, 1912. The LArcer, Oct. 21st, 3911, p. 1117. less optimistic temperament on the part of the physician in charge quite involuntarily affects the figures.

To begin with, in classifying the material it is impossible to obtain complete uniformity. In every classification into stages there must always be boundary cases which two observers may judge somewhat differently, so that it is hardly to be expected that two physicians will classify a great number of patients quite in the same way. Bat experience has shown that Turban's original division into stages, ${ }^{3}$ when his definition is followed exactly, answers practical requirements excellently, and gives figures which may very well be compared. This is especially the case when the Turban method of classification is supplemented by Sofus Bang's divisions of field, ${ }^{4}$ as used at all Danish sanatorinms since the year 1907. By this method as homogeneons results as possible are obtained.

While, as mentioned, a general comparison of the resnits at the time of discharge cannot be made, there are still some results which can be expressed numerically, and which, when due criticism is exercised, may be used for comparison. These are the disappearance of tubercle bacilli from the sputum, and a normal temperature at the completion of the treatment in patients who exhibited tubercle bacilli, or wexe febrile at the beginning of treatment.

A third fact which can be expressed numerically is the increase in weight, but this depends largely upon the patient's state of nourishment on admission. Well-to-do patients who have been properly fed before their admission will, as a rule, show less increase in weight than less wellto-do patients. While an average increase of weight for each patient during the treatment at Turban's sanatorium was 4 kilogrammes, at Vejlefjord sanatorium it was 5-8 kilogrammes. This need only indicate that Turban's patients were richer than our patients.

The percentage of patients who during treatment were relieved of tubercle bacilli in their expectoration can be seen from the following table :-

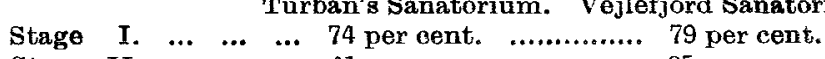

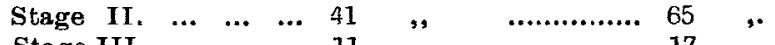

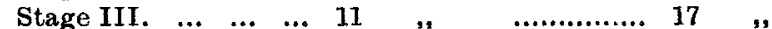

It will be seen that the figures throughont are more favourable at Vejlefjord Sanatorium than at the high-altitude sanatorinm.

The percentage of those patients who were admitted with fever but became afebrile during the treatment is follows :-

$$
\begin{aligned}
& \text { Stage I. } \ldots . . . \quad \ldots \quad 85 \text { per cent. ............. } 83 \text { per cent. }
\end{aligned}
$$

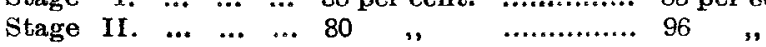

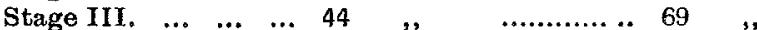

The figures cannot accurately be compared as the temperature is taken in the mouth at Turban's Sanatorium and in the rectum at Vejlefjord Sanatorium. These figures also show that the results are in no way better at Davos than at Vejlefjord Sanatorium. This fact is still more emphasised in that the average duration of the treatment at Turban's Sanatorium was 222 days, while at Vejlefjord Sanatorium it was, up to 1908,176 days.

When in practice an estimate is to be made of the results of a method of treatment, the question arises at once how the results will appear a number of years after its termination. The value of such an estimate is, however, limited, as the permanence of the results often are dependent upon circurnstances which are quite without any connexion with the treatment. And with pulmonary tuberculosis, where so much depends upon the patient's ability subsequently to take such precautions as are necessary in order to maintain the result gained, it is evident that the financial position of the patients is of great importance. When, therefore, a comparison is made between the results from Turban's Sanatorium and from Vejlefjord Sanatorium, it must be remembered that Tarban's charges are 50-100 per cent. higher than at Vejlefjord, the patients being considerably better off. For this reason it is to be expected that Turban's patients would keep in better health than those from Vejlefjord.

3 The Turban-Gerhard classification into stages "internationally adopted," unfortunately, is quite useless in the treatment of material such as ours; we would scarcely have 5 per cent. in Stage 1 . and $5-10$ per cent. in Stage II, and more than four-fifths of the patients in Stage III.

4 Zeitschrift fiir Tuberculoze, vol. xii., p. 384 
At both sanatoriums investigations concerning the later fate of the patients have been made-by Turban in the year 1897 for patients discharged from 1889-96, or 1-7 years after their discharge; at Vejlefjord Sanatorium every year since 1903, so that statistics compiled in 1911 inclade those patients who have been discharged from April, 1900December, 1908, or from 2-103 years after their discharge.

A simple comparison of figures is, as mentioned before, not permissible. Each separate stage comprises at both places most heterogeneous material, a most unequal number of cases, with or without tubercle bacilli in their sputum, and a great difference in the number of patients admitted with or without fever; and the figures are of course highly influenced thereby. It is therefore necessary to select a more exact limitation within the separate stages, and such a one presents itself quite naturally, partly in regard to the bacilli, and partly in regard to the temperattre. I have first made a comparison between the cases with bacilli-i.e., such cases where tabercle bacilli have been found in the sputum at the time of admission or during the stay at the sanatorium, within the separate stages, and the results of the comparison are given in Table 1 .

TABL I. - Statisties from Turban's Sanatorium and Vejlefjord Sanatorium regarding the Later Fate of Patients Admutted wath Tubercle Bacilli in their Sputum or in nhom Tuberole Baciliz have been Found during therr stay at the Sanatoriums.

\begin{tabular}{|c|c|c|c|c|c|c|}
\hline \multirow{2}{*}{-} & \multicolumn{3}{|c|}{$\begin{array}{l}\text { Turban's Sana- } \\
\text { torium (after } \\
\text { 1-7 years). }\end{array}$} & \multicolumn{3}{|c|}{$\begin{array}{l}\text { Vejlefjord Sana- } \\
\text { torium (after } \\
2-10^{3} \text { years). }\end{array}$} \\
\hline & $\begin{array}{c}\text { Stage } \\
\text { I. }\end{array}$ & Stage & $\begin{array}{l}\text { Stage } \\
\text { III. }\end{array}$ & $\begin{array}{c}\text { Stage } \\
\text { I. }\end{array}$ & $\begin{array}{l}\text { Stage } \\
\text { II. }\end{array}$ & $\begin{array}{l}\text { Stage } \\
\text { III. }\end{array}$ \\
\hline $\begin{array}{l}\text { 1. Able to do ordinary or light } \\
\text { work } \quad \ldots \quad \ldots l l l \\
\end{array}$ & 36 & 99 & 17 & 32 & 72 & 189 \\
\hline $\begin{array}{l}\text { 2. Unatie to work on account } \\
\text { of tratberculosis } \ldots \quad \ldots \quad \ldots\end{array}$ & 2 & 25 & 8 & 0 & 2 & 40 \\
\hline $\begin{array}{l}\text { 3. Unable to work on account } \\
\text { of other illnesses } \ldots \ldots\end{array}$ & 1 & 0 & 1 & 0 & 1 & 5 \\
\hline 4. Died from other illnesses ... & 0 & 1 & 2 & 4 & 3 & 11 \\
\hline 5. Died from tuberculosis $\quad \ldots$ & 0 & 54 & 73 & 3 & 26 & 522 \\
\hline 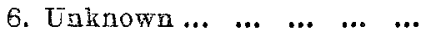 & 0 & 5 & 3 & 0 & 1 & 8 \\
\hline $\begin{array}{lllll}\text { Total... } & \ldots & \ldots & \ldots & \ldots\end{array}$ & 39 & 184 & 104 & 39 & 105 & $775^{5}$ \\
\hline
\end{tabular}

5 The considerable number of patients in the third stage at Vejlefjord Sanatorium is easily explained, for it is the only large sanatorium in Denmark intended for well-to-do, or fairly well-to-do, patients, and the anatorium is therefore always sought by a number of patients who are very ill. And all patients who apply are admitted if there is but zome possibility of improvement.

If the percentage is calculated, and Nos. 3 and 4 are omitted from this calculation (those who are otherwise ill or have died from other illnesses than tuberculosis, and whose fate does not influence the judgment of the present facts), then the figures will be as shown in Table II.

TAELE II. - Cases nith Baoilli (omitting those nho are ill or have died from other illnesses).

\begin{tabular}{|c|c|c|c|c|c|c|}
\hline 1. Able to work ... & $94 \cdot 7$ & $91 \cdot 4$ & $54 \cdot 0$ & $71 \cdot 3$ & $16 \cdot 8$ & $24 \cdot 7$ \\
\hline $\begin{array}{l}\text { 2. Unable to work on accoun } \\
\text { of tuberculosis } \ldots \text {... }\end{array}$ & $5 \cdot 3$ & & $13 \cdot 7$ & $2 \cdot 0$ & 79 & $5 \cdot 3$ \\
\hline 5. Died from tuberculosis & & $8 \cdot 6$ & $29 \cdot 6$ & $25 \cdot 7$ & $72 \cdot 2$ & 68 \\
\hline 6. Unknown $\ldots \begin{array}{lllll} & \ldots & \ldots & \ldots & . .\end{array}$ & - & - & $2 \cdot 7$ & 10 & 3.0 & $1 \cdot 2$ \\
\hline
\end{tabular}

Table II. shows that although a considerably longer period has passed from the time of discharge, still the results from Veilefjord Sanatoriam are in no way inferior to those from Turban's Sanatoriam, and that they are even considerably better with regard to the more severe forms of the disease.

The other relatively homogeneous category within each separate stage is composed of those patients who have been admitted to the sanatorinm with fever. The results for patients admitted with ferer at the two sanatoriums are shown in. Table III.

TABLE III. - Statistics from Turban's Sanatorium and Vejlefjord Sanatorium regarding the Later Fate of Patients admitted with Fever.

1. Able to do ordinary or light

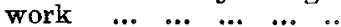

2. Unable to work on account of tuberculosis ... ... ...

3. Unable to work on account of other illnesses $\quad \ldots$... 4. Died from other illnesses ... 5. ,, ," tuberculosis .. 6. Unknown ... Totals $\quad \ldots \quad \ldots \quad \ldots \quad \ldots$

\begin{tabular}{|c|c|c|c|c|c}
$\begin{array}{c}\text { Turban's Sana- } \\
\text { torium (after } \\
1-7\end{array}$ & \multicolumn{2}{|c}{$\begin{array}{c}\text { Vejlefjord Sana- } \\
\text { torium (after } \\
\text { 2-103 years). }\end{array}$} \\
\hline $\begin{array}{c}\text { Stage } \\
\text { I. }\end{array}$ & $\begin{array}{c}\text { Stage } \\
\text { II. }\end{array}$ & $\begin{array}{c}\text { Stage } \\
\text { I11. }\end{array}$ & $\begin{array}{c}\text { Stage } \\
\text { I. }\end{array}$ & $\begin{array}{r}\text { Stage } \\
\text { II. }\end{array}$ & $\begin{array}{c}\text { Stage } \\
\text { III. }\end{array}$ \\
\hline 18 & 40 & 10 & 20 & 37 & 91 \\
0 & 13 & 6 & 0 & 0 & 15 \\
0 & 0 & 0 & 0 & 0 & 2 \\
0 & 0 & 1 & 2 & 1 & 6 \\
1 & 34 & 63 & 0 & 11 & 336 \\
1 & 3 & 2 & 0 & 0 & 2 \\
\hline 20 & 90 & 82 & 22 & 49 & 452 \\
\hline
\end{tabular}

Table IV. is a re-calculation of Table III. to percentage figures in the same way as Table II. in its relation to Table 1 .

TABLE IV.-Febrile Cases (omitting those who are ill or have dued from other illuesses).

\begin{tabular}{|c|c|c|c|c|c|c|}
\hline \multirow[b]{2}{*}{-} & \multicolumn{2}{|c|}{ Stage $\mathrm{I}$. } & \multicolumn{2}{|c|}{ Stage II. } & \multicolumn{2}{|c|}{ Stage III. } \\
\hline & 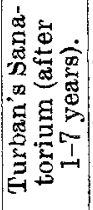 & 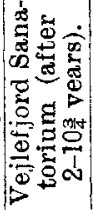 & 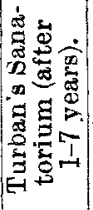 & 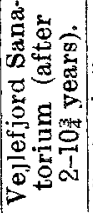 & 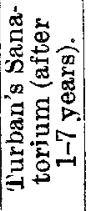 & 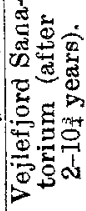 \\
\hline & $\begin{array}{l}\text { Per } \\
\text { cent. }\end{array}$ & $\begin{array}{c}\text { Per } \\
\text { cent. }\end{array}$ & $\begin{array}{c}\text { Per } \\
\text { cent. }\end{array}$ & $\begin{array}{c}\text { Per } \\
\text { cent. }\end{array}$ & $\begin{array}{c}\text { Per } \\
\text { cent. }\end{array}$ & $\begin{array}{l}\text { Per } \\
\text { cent. }\end{array}$ \\
\hline 1. Able to work $\quad \ldots \quad$.. & 90 & 100 & $44 \cdot 4$ & $77 \cdot 1$ & $12 \cdot 3$ & 205 \\
\hline $\begin{array}{l}\text { 2. Unable to work on account } \\
\text { of tuberculosis } \ldots \text {... } \quad \ldots\end{array}$ & - & - & $14 \cdot 4$ & - & $7 \cdot 4$ & 39 \\
\hline 5. Died from tuberculosis $\quad$... & 5 & - & $37 \cdot 8$ & $22 \cdot 9$ & $77 \cdot 7$ & $75 \cdot 6$ \\
\hline 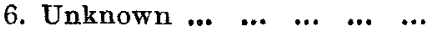 & 5 & - & $3 \cdot 3$ & 一 & $2 \cdot 5$ & 0.5 \\
\hline
\end{tabular}

As will be seen, Table IV. tells the same story as the table for the cases with bacilli, and shows that the results obtained at Vejlefjord Sanatorium, situated by the sea coast and just above the level of the sea, are more favourable as far as the severely, and even the most severely, attacked patients are concerned than the results obtained at Turban's Sanatorium, which is situated 1573 metres above the sea. The table also shows that the results are about the same at the two sanatoriums as far as the slighter cases are concerned.

Eren if the possibility is taken into consideration that pulmonary tuberculosis in the course of time seems to show a certain tendency to take a milder course than before-a possibility I am personally not inclined to deny-and that the ten years which have elapsed between the dates treated by the two sets of statistics might have a slight inflaence in favour of our statistics, still I consider myself entitled to hold as proved that by the treatment of pulmonary tuberculosis in the lowlands it is possible to obtain results which are just as favourable as the results obtained at high altitudes - results that for Stiges II. an 1 III. of the disease are even better. 